\title{
Knowledge, attitudes, behaviours and practices towards diabetes mellitus in Kuwait
}

Manuel Carballo ${ }^{1,2}$, Anwar Mohammad ${ }^{1}$, Elizabeth C. Maclean ${ }^{2}$, Noureen Khatoon ${ }^{1}$, Mohammad Waheedi ${ }^{3}$ and Smitha Abraham ${ }^{1}$

${ }^{1}$ Dasman Diabetes Institute, Kuwait. ${ }^{2}$ International Centre for Migration, Health and Development, Geneva, Switzerland (Correspondence to: M. Carballo: mcarballo@icmhd.ch). ${ }^{3}$ Department of Pharmacy Practice, Kuwait University, Kuwait

\begin{abstract}
Background: Rates of diabetes in Kuwait are among the highest in the world.

Aims: To inform prevention initiatives, this study assessed diabetes knowledge, attitudes towards it, and personal behaviour relating to risk factors among the Kuwaiti population.

Methods: A cross-sectional knowledge, attitudes, beliefs and practices survey of 1124 people was performed between July and September 2015. Descriptive analysis and $\chi_{2}$ tests were performed.

Results: Although most participants (94\%) had heard of diabetes and 87\% believed type 2 diabetes to be preventable, knowledge of risk factors was poor [family history (87\%), age (44\%), low exercise (10\%), obesity (4\%), diet (0\%) and stress $(0 \%)$. Dietary patterns in Kuwait were variable and, of concern, $42 \%$ of those with diabetes had been eating more since diagnosis. Lifestyle, particularly among Kuwaitis and people with diabetes, was sedentary - 47\% of participants walked < 20 minutes per day.

Conclusions: Despite the importance of diet and exercise for diabetes prevention, significant gaps in public education clearly exist. At a policy level, much remains to be done and intensified intersectoral programmes are required to improve public awareness.

Keywords: diabetes mellitus, diet, exercise, Kuwait, prevention.

Citation: Carballo M; Mohammad A; Maclean EC; Khatoon N; Waheedi M; Abraham S. Knowledge, attitudes, behaviours and practices towards diabetes mellitus in Kuwait. East Mediterr Health J. 2018;24(11):1098-1102. https://doi.org/10.26719/2018.24.11.1098

Received: 20/04/17; accepted: 15/08/17

Copyright (C) World Health Organization (WHO) 2018. Some rights reserved. This work is available under the CC BY-NC-SA 3.0 IGO license (https:// creativecommons.org/licenses/by-nc-sa/3.o/igo).
\end{abstract}

\section{Introduction}

Type 1 and type 2 diabetes have become a major health and healthcare challenge in Kuwait and other parts of the world. Globally, over 415 million people are thought to be now living with the disease, and up to $12 \%$ of health expenditure is currently taken up by its treatment and care (1). In the Gulf Cooperation Council region (Bahrain, Kuwait, Oman, Qatar, United Arab Emirates and Saudi Arabia) where the prevalence of obesity has increased in the last 3 decades, diabetes rates have also risen and are now among the highest anywhere in the world $(2,3)$.

The fact that type 2 diabetes, which is by far the more common form of the disease, is largely preventable with a mix of dietary management and physical exercise, calls for an understanding of how people perceive the threat of diabetes and what they feel can be done to prevent it. A growing body of evidence from surveys on the knowledge, attitudes, beliefs and practices (KABP) of people in different parts of the world suggests that sizable gaps exist with respect to public awareness of the risk factors for diabetes and how these factors can be avoided or mitigated (4-6).

In order to inform and guide national prevention initiatives in Kuwait, this study looked at what people know about diabetes, what their attitude to it is, what they believe are its causes and how their personal behaviour may relate to diabetes and its risk factors.

\section{Methods}

\section{Ethics statement}

The study was approved by the Ethical Review Committee and International Scientific Advisory Board of the Dasman Diabetes Institute, Kuwait. All participants gave signed informed consent.

\section{Study design}

A random-sample, cross-sectional KABP survey was designed, and a standardized questionnaire was developed and pretested by the Dasman Diabetes Institute, building on previous validated KABP surveys and guidelines $(7,8)$. Face validity of questions was determined by expert review. Medical students from the University of Kuwait were trained in the reliable use of the questionnaire that was then used in face-to-face interviews or self-completed by participants selected in shopping malls and government offices. Questionnaires were available in both English and Arabic, so as to cover the large expatriate population in Kuwait as well as Kuwaiti nationals. The survey was undertaken between July and September 2015. A total of 1124 people were invited to participate. 
Only adults over the age of 21 years $(n=1088)$ were included in the analysis.

\section{Data analysis}

Data were analysed using SPSS version 21, with $P=0.05$ as the significance level. Frequencies and descriptive statistics were used to assess the data, with $\chi^{2}$ and odds ratios being used to compare groups. Confidence intervals (CIs) were assessed at 95\%. For height, weight and body mass index, outliers were removed based on $\mathrm{z}$ scores $>3$ standard deviations from the mean.

\section{Results}

\section{Demographics}

Of the 1088 people who were selected, 566 were female and 522 were male. The higher proportion of women may reflect that most of the interviews were conducted in shopping malls. In all, 647 (59.5\%) participants were non-Kuwaiti and $441(40.5 \%)$ were Kuwaiti. The main countries of origin for non-Kuwaitis were Egypt (17\%), India (12\%), Philippines (6\%), Pakistan (4\%), Syrian Arab Republic (4\%), Lebanon (3\%) and Jordan ( $2 \%$ ). The mean number of years that expatriates had spent in Kuwait was 14.4 (standard deviation 11.4; 95\% CI 13.5-15.3). According to national estimates, $69 \%$ of the Kuwait population is expatriate (8); therefore, non-Kuwaitis were underestimated in our sample. The educational level of the participants was high; $642(60 \%)$ had completed a university education and $123(12 \%)$ had postgraduate degrees. According to self-reported height and weight measures, $36 \%$ of the respondents were overweight and $24 \%$ were obese. Furthermore, 101 participants (9.3\%) stated that they had been diagnosed with diabetes.

\section{Diabetes knowledge}

The vast majority $(806,93.9 \%)$ of the respondents said they had heard of diabetes before the interview, and 662 (65.5\%) had a family member who had been diagnosed with diabetes; in $64 \%$ of these cases the family member was a parent or sibling. Indeed, 944 (86.8\%) respondents said that they saw diabetes as a disease that runs in the family, and respondents who had a relative with diabetes were significantly more likely to recognize the hereditary traits of the disease $(P<0.001)$. All participants with family members with diabetes stated that it ran in the family.

Almost half $(474,44 \%)$ of the respondents also saw age as a risk factor for diabetes, agreeing with the statement that "you get it when you get older". Older participants were nevertheless more likely than younger people to see age as a risk factor for diabetes $(P=0.048)$, and nonKuwaitis were more likely than Kuwaitis (51.5\% and 32\%) to see age as a risk factor $(P<0.001)(\mathrm{OR}=2.256 ; 95 \% \mathrm{CI}$ 1.75-2.9).

Despite $36 \%$ of participants being overweight and $24 \%$ being obese, only $41(3.8 \%)$ respondents saw obesity as a risk factor for diabetes.

While $865(87 \%)$ respondents recognised that type 2 diabetes is preventable, none of them highlighted poor diet as a factor, and the preventative role of exercise was only recognized by $112(10.3 \%)$ respondents. Among those who acknowledged the preventative role of exercise, a higher proportion $(16.8 \%)$ was aged $21-30$ years $(P<0.001)$. Stress was not seen by anyone as a contributing factor, and no one agreed with fatalistic statements such as "just God's will" and "it just happens".

\section{Dietary beliefs and practices}

Almost half $(498,46.7 \%)$ of all participants felt that food was expensive in Kuwait, and $372(35 \%)$ felt that pre-prepared food was often cheaper than buying ingredients. Many $(433,40.8 \%)$ also said they did not have time to prepare food themselves and that it was easier than trying to cook at home $(643,60.7 \%)$. Most $(712,67.2 \%)$ respondents nevertheless agreed that home-cooked meals tasted better, and only $25 \%$ said it was hard to find the types of food that they liked. No significant differences were observed between Kuwaiti and non-Kuwaitis $(P=0.428)$ in their ability to find food that they liked.

Food consumption patterns are shown in Table 1. Almost half the participants stated that they usually do not drink soft drinks, and people living with diabetes were more likely to drink fewer soft drinks per day than other people were $(P=0.005)$. However, no differences were found between people with and without diabetes regarding the number of meals/snacks consumed per day $(P=0.260)$. Although almost a third $(30.4 \%)$ of people living with diabetes said that they had been eating less since being diagnosed with the disease, $42.2 \%$ said they had been eating more.

\section{Attitude and behaviour towards exercise}

Lifestyle in Kuwait has become sedentary, and 183 (17.2\%) respondents indicated that they almost never walk, and another $319(29.9 \%)$ said that they only walked 1-20 minutes per day. Walking and exercise patterns are summarized in Table 2. Different trends were found among Kuwaitis and non-Kuwaitis, with the former spending less time on physical activity such as walking $(P<0.001)$ or other forms of exercise $(P<0.001)$. People living with diabetes were more sedentary than others; out of 100 people diagnosed with diabetes, 34\% stated that they never walk compared to $14.9 \%$ among those who did not have diabetes $(P=0.001)$. In all, only $31(30.1 \%)$ of those living with diabetes stated that they had increased their level of exercise since being diagnosed. No significant difference was seen in changes in physical activity over the past year between those with and without diabetes $(P=0.631)$. Over half $(52 \%)$ of the people with diabetes and $48.9 \%$ who did not have diabetes said they were now spending less time walking or exercising compared to the previous year. Reasons for not doing more exercise varied and are summarized in Table 3; 11.3\% of people with diabetes said they were too tired to exercise and $60.1 \%$ said that since their diagnosis they had been sleeping more.

\section{Discussion}

KABP surveys can provide valuable insights into how 


\begin{tabular}{|c|c|c|}
\hline Dietary behaviour & Frequency & Valid \% \\
\hline \multicolumn{3}{|l|}{ No. of meals/snacks per day } \\
\hline 1 or 2 & 420 & 38.6 \\
\hline 3 or 4 & 572 & 52.6 \\
\hline 5 or 6 & 76 & 7.0 \\
\hline$>6$ & 14 & 1.3 \\
\hline \multicolumn{3}{|l|}{ Fruit eating habits } \\
\hline Never & 74 & 6.8 \\
\hline Once weekly & 255 & 23.5 \\
\hline Twice weekly & 236 & 21.8 \\
\hline Three times or more weekly & 518 & 47.8 \\
\hline \multicolumn{3}{|l|}{ Vegetable eating habits } \\
\hline Never & 43 & 4.0 \\
\hline 1 or 2 times weekly & 158 & 14.6 \\
\hline 3 or 4 times weekly & 239 & 22.1 \\
\hline$>4$ times weekly & 642 & 59.3 \\
\hline \multicolumn{3}{|l|}{ Red meat eating habits } \\
\hline Never & 123 & 11.4 \\
\hline 1 or 2 times weekly & 516 & 47.8 \\
\hline 3 or 4 times weekly & 350 & 32.4 \\
\hline 5 or 6 times weekly & 64 & 5.9 \\
\hline$>6$ times weekly & 27 & 2.5 \\
\hline \multicolumn{3}{|l|}{ White meat eating habits } \\
\hline Never & 33 & 3.0 \\
\hline 1 or 2 times weekly & 416 & 38.4 \\
\hline 3 or 4 times weekly & 460 & 42.5 \\
\hline 5 or 6 times weekly & 111 & 10.3 \\
\hline$>6$ times weekly & 62 & 5.7 \\
\hline \multicolumn{3}{|l|}{ Dairy eating/drinking habits } \\
\hline Never & 83 & 7.7 \\
\hline 1 or 2 times weekly & 245 & 22.9 \\
\hline 3 or 4 times weekly & 295 & 27.9 \\
\hline 5 or 6 times weekly & 172 & 16.1 \\
\hline$>6$ times weekly & 274 & 25.6 \\
\hline \multicolumn{3}{|c|}{ Sweet soft drink consumption habits } \\
\hline None & 530 & 49.6 \\
\hline 1 or 2 drinks daily & 375 & 35.1 \\
\hline 3-5 drinks daily & 118 & 11.0 \\
\hline$>5$ drinks daily & 45 & 4.2 \\
\hline
\end{tabular}

people view health and healthcare problems, and if and to what extent their personal behaviour may be placing them at risk. In our study, participants were selected at shopping malls and government offices. This method was used in order to maximize the likelihood of obtaining a representative cross-section of the Kuwaiti population. Reaching the expatriate community can be difficult using other sampling methods and previous experience with epidemiological surveys in Kuwait has also pointed to serious difficulties in recruiting Kuwaitis by telephone and household surveys. However, selection at these loca-

\begin{tabular}{|c|c|c|}
\hline Exercise behaviour & Frequency & Valid \% \\
\hline \multicolumn{3}{|c|}{ Time spent walking per day } \\
\hline (almost) never walk & 183 & 17.2 \\
\hline $1-20 \mathrm{~min}$ & 319 & 29.9 \\
\hline $21-30 \mathrm{~min}$ & 193 & 18.1 \\
\hline $31-60 \mathrm{~min}$ & 141 & 13.2 \\
\hline$>1 \mathrm{~h}$ & 109 & 10.2 \\
\hline$>2 \mathrm{~h}$ & 122 & 11.4 \\
\hline \multicolumn{3}{|c|}{ Average time per day spent doing other physical exercises } \\
\hline None & 462 & 42.5 \\
\hline $1-20 \mathrm{~min}$ & 229 & 21.0 \\
\hline $21-30 \mathrm{~min}$ & 151 & 13.9 \\
\hline $31-60 \mathrm{~min}$ & 127 & 11.7 \\
\hline$>1 \mathrm{~h}$ & 91 & 8.4 \\
\hline$>2 \mathrm{~h}$ & 28 & 2.6 \\
\hline \multicolumn{3}{|l|}{ Other physical exercises } \\
\hline Fast walking & 141 & 13.4 \\
\hline Jogging & 106 & 10.1 \\
\hline Swimming & 63 & 6.0 \\
\hline Cycling & 30 & 2.8 \\
\hline Yoga & 28 & 2.7 \\
\hline Other & 141 & 13.4 \\
\hline \multicolumn{3}{|c|}{$\begin{array}{l}\text { Changes in time spent walking or doing } \\
\text { physical exercises in the past year }\end{array}$} \\
\hline Less & 470 & 49.1 \\
\hline About the same & 264 & 27.6 \\
\hline More & 223 & 23.3 \\
\hline
\end{tabular}

tions could have biased our sample, particularly in terms of educational attainment and socioeconomic status. As such, the results of this study should be considered as a pilot for future research in the region using randomized selection methods. This initial KABP study has, nevertheless, highlighted several concerns and challenges facing Kuwait, where a combination of diabetes and obesity has become a major threat to public health.

While most people in this study had heard about diabetes and knew of people within their social network who were living with the condition, there appeared to be little sensitivity to many of the key factors involved. Most people saw family history of diabetes as a risk factor, but fewer seemed to see obesity, lack of exercise, dietary behaviour and ageing as associated with the risk of diabetes. Despite the importance of diet and exercise in the prevention and management of diabetes, few study participants seemed to see a need to change their diet, and there was little difference in dietary behaviour between people living with diabetes and others. Even more strikingly, almost half of those living with diabetes said they had been eating more since being diagnosed.

Another concern is the large numbers of participants who said that they were not engaged in any exercise that might help them to avoid diabetes. Approximately two 


\begin{tabular}{lcc}
\hline $\begin{array}{l}\text { Table } 3 \text { Reasons for not increasing exercise routine among } \\
\text { people living with diabetes }\end{array}$ & $\begin{array}{c}\text { Frequency } \\
(\mathbf{n = 8 0})\end{array}$ & Valid \% \\
\hline Reason for not exercising more & 31 & 38.8 \\
Not enough time & 24 & 30.0 \\
Too hot & 9 & 11.3 \\
Too tired & 7 & 8.8 \\
Do not like doing exercise & 1 & 1.3 \\
Not in my culture & 1 & 1.3 \\
Not in the culture of Kuwait & 7 & 8.8 \\
Other & & \\
\hline
\end{tabular}

thirds of people living with diabetes indicated that this was either because they did not have the time or because it was too hot. The latter reason is understandable given the climate in Kuwait, where, for $\geq 4$ months of the year extreme heat makes outdoor exercise difficult. However, the advent of many large air-conditioned shopping malls and gyms in most neighbourhoods of Kuwait City has made year-round walking feasible. Given the results of this study, however, there is a clear need to enhance the promotion of exercise in these facilities, especially among Kuwaiti nationals and people living with diabetes; both of whom were less likely than others to be regularly exercising.

In a society where $20 \%$ of the population is now estimated to be living with diabetes (1), and where the key to avoiding an even larger epidemic is primary and secondary prevention, it is difficult not to conclude that the response to diabetes has been passive at best, and has clearly not been given the priority it calls for. Certainly, in the area of public information and education, major gaps in knowledge have emerged with respect to factors contributing to diabetes. Thus, despite the magnitude of the problem, a significant proportion of the lay community remains ignorant of the way in which diabetes develops and what steps can be taken to avoid or mitigate its impact. Tailoring information and education around the KABP characteristics that have been identified in this study will be a step toward overcoming these gaps. Developing ways of seeding factual and socially acceptable information and then segmenting it by social KABP features will be equally important, and in this regard diabetes information/education strategies should take into consideration the demographic and ethnic diversity of Kuwait and identify ways of reaching different age groups as well as country-of-origin groups.

At a policy level, there is also much to be done. The promotion of physical exercise as a public health measure calls for commitment by a mix of government and employers as well as the public at large. Making physical exercise and education a more central and routine part of school activity, for example, is key to helping ensure the health of adolescents in Kuwait. Similarly, more needs to be done to bring employers and employees together in public-private programmes of education information and exercise in the workplace. Intensified programmes of intersectoral action by ministries of health, education and labour are now called for if public awareness about diabetes is to be improved and if people are to be encouraged to take action to avoid diabetes, or manage it well if they have already developed it. With the success of this initial survey, similar studies should now be implemented in other Arabic countries where research of this kind could inform regionwide initiatives to tackle the growing diabetes epidemic.

\section{Acknowledgements}

The authors thank Kuwait University medical students for their help in the collection of survey data.

Funding: None.

Competing interests: None declared.

\section{Connaissance, attitudes, comportements et pratiques associés au diabète sucré au Koweït}

\section{Résumé}

Contexte : Les taux de diabète au Koweït sont parmi les plus élevés au monde.

Objectifs : La présente étude avait pour objectif d'évaluer les initiatives de prévention en examinant les connaissances relatives au diabète, les attitudes associées, et les comportements personnels liés aux facteurs de risque parmi la population koweitienne.

Méthodes : Une étude transversale portant sur les connaissances, les attitudes, les croyances et les pratiques a été menée auprès de 1124 individus entre juillet et septembre 2015. Une analyse descriptive et des tests du $\chi 2$ ont été réalisés.

Résultats : Même si la plupart des participants $(94 \%$ ) avaient entendu parler du diabète et $87 \%$ pensaient que le diabète de type 2 pouvait être évité, la connaissance des facteurs de risque était faible [antécédents familiaux (87\%), âge (44\%), peu d'activité physique $(10 \%)$, obésité $(4 \%)$, régime alimentaire $(0 \%)$ et stress $(0 \%)$ ]. Les habitudes alimentaires étaient variables au Koweït, et $42 \%$ des personnes diabétiques mangeaient plus depuis que la maladie avait été diagnostiquée, ce qui était préoccupant. Le mode de vie, particulièrement parmi les citoyens koweïtiens et les personnes diabétiques, était sédentaire ( $47 \%$ des participants marchaient moins de 20 minutes par jour). 
Conclusion : Malgré l'importance du régime alimentaire et de l'activité physique dans la prévention du diabète, des écarts significatifs existent dans l'éducation du public. Au niveau politique, un travail considérable reste à effectuer et une intensification des programmes intersectoriels est nécessaire afin de sensibiliser davantage le public.

$$
\begin{aligned}
& \text { المعلو مات والاتجاهات و السلوكيات والملمارسات تجاه السكري في الكويت } \\
& \text { مانويل كاربالو، أنور محمد، إليز ابيث ماكلين، نورين خاتون، محمد وحيدي، سميثا أبراهام } \\
& \text { الخلاصة } \\
& \text { الخلفية: تعتبر معدلات السكري في الكويت من أعلى المعدلات في العالم. }
\end{aligned}
$$

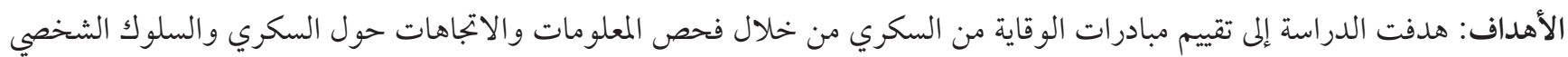

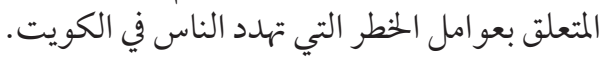

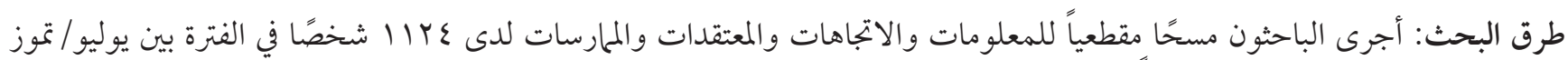

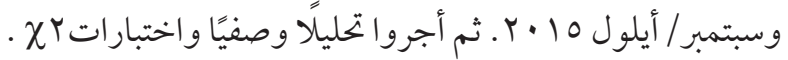

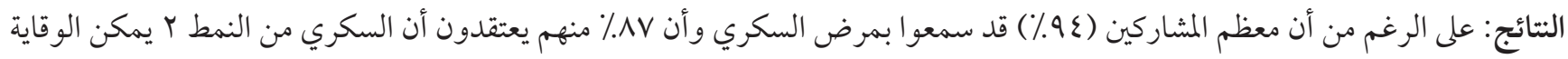

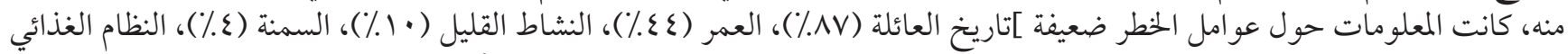

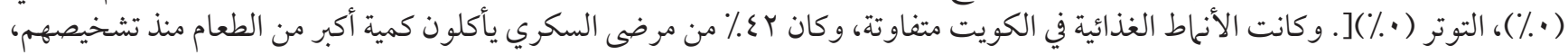

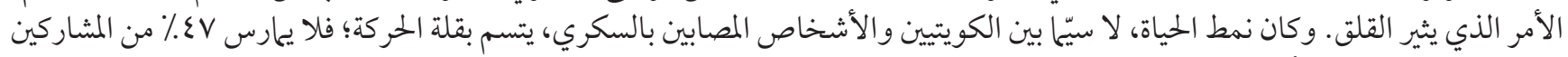

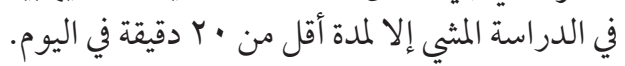

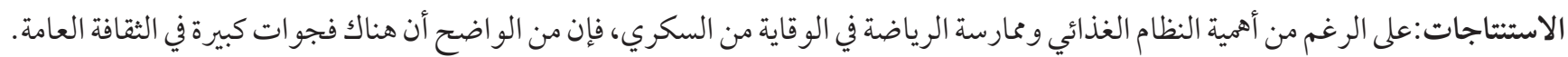

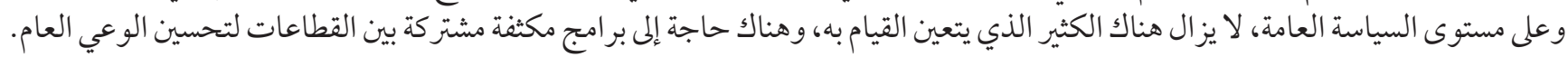

\section{References}

1. Diabetes atlas. 7th edition. Brussels: International Diabetes Federation; 2015

2. Ziyab AH, Mohammad A, Maclean E, Behbehani K, Carballo M. Diabetes: a fast evolving epidemic. Kuwait Med J. 2015;47(4):291301.

3. Guariguata L, Whiting DR, Hambleton I, Beagley J, Linnenkamp U, Shaw JE. Global estimates of diabetes prevalence for 2013 and projections for 2035. Diabetes Res Clin Pract. 2014 Feb;103(2):137-49. https://doi.org/10.1016/j.diabres.2013.11.002 PMID:24630390

4. Al-Maskari F, El-Sadig M, Al-Kaabi JM, Afandi B, Nagelkerke N, Yeatts KB. Knowledge, attitude and practices of diabetic patients in the United Arab Emirates. PLoS One. 2013;8(1):e52857. https://doi.org/10.1371/journal.pone.0052857 PMID:23341913

5. Demaio AR, Otgontuya D, de Courten M, Bygbjerg IC, Enkhtuya P, Oyunbileg J, et al. Exploring knowledge, attitudes and practices related to diabetes in Mongolia: a national population-based survey. BMC Public Health. 2013 Mar 18;13(1):236. https://doi. org/10.1186/1471-2458-13-236 PMID:23506350

6. Islam FMA, Chakrabarti R, Dirani M, Islam MT, Ormsby G, Wahab M, et al. Knowledge, attitudes and practice of diabetes in rural Bangladesh: the Bangladesh Population based Diabetes and Eye Study (BPDES). PLoS One. 2014 Oct 14;9(10):e110368. https:// doi.org/10.1371/journal.pone.0110368 PMID:25313643

7. Mehryar A, Carballo M, Carael M, Muhondwa E. KABP surveys: an introduction to basic concepts, methodology and references. Geneva: Global Programme on AIDS; 1989

8. The World Fact Book: Kuwait [website]. Central Intelligence Agency (https://www.cia.gov/library/publications/the-world-factbook/geos/ku.html, accessed 8 August 2018). 